Covered in: ERIH PLUS, CEEOL, Index Copernicus, CrossRef, CrossCheck, J-Gate, Google Scholar, Ideas RePeC, Econpapers, Socionet, KVK, WorldCat.

\section{Military Conflict in Eastern Ukraine and its Social and Political \\ Dimensions}

\section{Andrii POSPIELOV1}

${ }^{1} \mathrm{Ph} \mathrm{D}$ in History, ODC «Odessa Academy of Continuing Education of Odessa Regional Council», Odesa, Ukraine, E-mail: andreas.pospelov@gmail.com
Abstract: Social networks have become tools of geopolitical influence that Russia fully used during annexation of Crimea and inflaming of war in Eastern Ukraine. The pro-Russian pages "In Contact" created the image of Ukraine as a foreign country for the population of Donbas and Crimea, Southeastern Ukraine - as a part of Greater Russia, NATO and the EU - as the main enemies whose actions have led to the conflict. The narrative concerning Ukraine was dominated by the theme of describing the actions of the Ukrainian military and the Ukrainian authorities as "punishers", making an emotional message and appealing to allegories of World War II, which was intended to deepen the sense that Ukraine is an enemy. The second dominant issue was the questioning of Ukraine as a political entity, through appealing to it as for "failed political project". The third dominant issue for Ukraine was the widespread criticism of former-Ukrainian authorities, which was referred to as the "Kyiv authorities" to emphasize the differences between the interests of the Center and local interests. Abovementioned issues of the geopolitical narrative were complemented by issues of domination of oligarchs in Ukraine, who exploited the population and allowed themselves to violate human rights and freedoms. Russia, in its turn, created for itself the image of a "great state" capable of resisting the enemy and being culturally closer to Southeastern Ukraine (so called the concept of "Novorosiya"). The annexation of Crimea was used as the sample of "success story" in pro-Russian narratives.

Keywords: Military conflict; great state; parallel state; social networks; geopolitical influence.

How to cite: Pospielov, A. (2020). Military Conflict in Eastern Ukraine and its Social and Political Dimensions. Logos Universality Mentality Education Novelty: Philosophy \& Humanistic Sciences, 8(1), 20-32. doi: 10.18662/lumenphs/8.1/33 


\section{Introduction}

The military-political conflict in Eastern Ukraine, which has been going on since April 2014, is unique in recent world history. Its political and scientific classification is extremely complicated due to the fact that participation of the parties involved in this conflict differs in facts and time. This is reflected even in the not identical names of the conflict in the eastern Ukraine that officially and not officially accepted in Ukraine, other countries of the world, especially in Europe and Russia.

\section{Problem Statement}

At present, the historiographical work on the conflict in Eastern Ukraine is very significant. The bulk of the researches belongs to Ukrainian authors, whose positions are sometimes quite different. However, they are united in their almost identical attitude to this conflict as a regional event provoked by the policy of the Russian Federation government. At the same time, this conflict is usually evaluated from the point of view of historical analogies (Gay-Nyzhnik, 2017), the chronology of developments in positivist scientific methodology (Troyan \& Kiridon, 2008) and analyzed from the sociological point of view (Rushchenko, 2015).

However, key aspects of the military conflict in Eastern Ukraine remain out of the limelight of researchers. It is a "concert of states" involved in it, as a key factor in the origin and proceeding of this conflict, a key cause of its emergence and, most importantly, its geopolitical deadlock. By the last term we mean the actions of the parties directly involved in the conflict, not after its termination, but after its freezing.

It is these three aspects that underpin our publication, which seeks to bridge this scientific gap.

\section{Aims of the research}

The purpose of our study is to examine the root causes of the military conflict in the East of Ukraine, to analyze its main structural components in the form of all state entities involved in this conflict ("concert of states") - geopolitical actors, and to define the factors due to which, in the present moment, appears the tendency not to political termination of the military conflict in the East of Ukraine, but to its freezing. In addition, our task is to identify trends for the future that have given rise to a military conflict in the Eastern Ukraine. All aspects presented are the author's concept of analyzing this conflict. 


\section{Research Methods}

The basis of our analysis is the methods of historicism, geopolitical analysis and analogies. Owing to these presented methods, we were able to analyze qualitatively and carefully the military conflict in the East of Ukraine from unaffiliated positions.

The basic methodological concept of our analysis is positivism in postmodern variation. At the same time, in order to analyze the "causes and effects" factors of the conflict in the East of Ukraine, we have used basically the methodological conception of the well-known Russian historian of the 19th century. V. Klyuchevsky. It is this that puts the character of the territories of the state and its related factors at the forefront of root causes of all historical events.

\section{Findings}

It is obvious that unique political configuration has not had yet precedents in history. The main and key characteristic of the conflict in the east of Ukraine is that it is a conflict between a standard, officially recognized world state - Ukraine, with no official allies or efficient coalition, against the de facto and de jure «great state» - the Russian Federation.

Indeed, it is very often happens in history that great powers have waged wars against states that are not in this category. However, in this case, the situation developed in one of two scenarios. 1. The great power captured the state not a great (this was very common). 2. The great power, in an attempt to subdue not a great state has come into conflict with it and often even lose, exclusively because there was another great power or even union behind the back of a great state. Thus, the conflict began between the great powers, but because of the state not a great had only indirect character. The classic examples here are the Korean (1950-1953) and the Vietnam (19641975) wars.

The situation in the East of Ukraine is fundamentally different behind Ukraine, which is not a great state, no other great state or even a viable coalition. However, the Russian Federation as a great power, which, even through specially created structures (so called Lugansk and Donetsk Peoples Republics or LDPR) indirectly conducts hostilities against Ukraine, has not achieved its goals.

As a result, the situation that arose in April 2014 does not even have a theoretical solution nowadays, as evidenced by the working processes of freezing or reducing the intensity of this conflict in the peacekeeping 
rhetoric of each of the parties, which to one degree or another (Ukraine, RF) or indirectly (some NATO and EU countries) interested in eliminating it.

In order to understand why such sort of affairs did happen or why a great state pursues the goal of certain freezing the conflict in the East of Ukraine, it should be highlighted through a system of causal-conceptual coverage. Namely, through the exposition of the reasons that forced the Russian Federation to resort to kindling an armed confrontation in the East of Ukraine and through an attempt to classify this conflict as a worldhistorical phenomenon in the scientific-theoretical background.

First of all, it should be noted that at the beginning of the second decade of the 21 st century it became quite clear to the leadership of the Russian Federation that, although it is a great state de jure, in fact, it is not correspond to this status. That is, it is officially the successor to the Soviet Union, but in attempts to pursue a similar foreign policy, the Russian Federation cannot reach USSR level due to a number of objective factors. Firstly, the Russian Federation objectively lacks a population that is rapidly stratifying and migrating, but not so much within the territory of the Russian Federation as abroad.

Secondly, it was that the famous American researcher Robert Kaplan (Kaplan, 2015) called "revenge of geography". The colossal size of the territory, the need to be able to protect its interests at least along the perimeter of borders, makes it impossible for Russia to be strong everywhere. All this is tied with the fact that there where the Russian Federation has (theoretically) geopolitical advantages, it has been leveled by the policy of the 1990s. This is most clearly seen in the basins of the Baltic and Black Seas, where the emergence of new independent states, including Ukraine, significantly restricted any opportunities of the Russian Federation.

Thirdly, it is a drastic decrease in defense-industrial and defensescientific potentials, both for objective reasons - a number of relevant enterprises remained outside the Russian Federation in the newly independent states, and for subjective reasons, especially. By the latter we mean the collapse of a large number of Russian science schools because of the economic turmoil of the 1990s and early 2000s. As a result, this made the Russian defense industry unable to reach a new conceptual and technological level, whereas in the early 2010s the Ukrainian and Belarusian defense industry reached it. That is, all Russian technologies, especially for defense purposes, have been based on the reserves of the USSR and actually reached the limits of their development at the beginning of the analyzed decade. 
For the Russian Federation, an economy that is essentially bicultural, that is, directly dependent on the export of energy and products of the domestic defense industry, it could lead to a dead crisis in the early 2010's.

All this was clearly manifested during the so-called Syrian crisis, which began with the start of the civil war in the SAR in March 2011. It was revealed in it that the Bashar Assad regime de facto is really the last ally of the Russian Federation in the so-called far abroad, and the point of material - technical support of the Russian fleet in the Syrian port of Tartus is the last Russian military base there. Protracted hesitations to help or ignore his ally led to the losing of time from the side of Moscow. When the decision to assist the Assad regime was taken at the highest level, another problem emerged - the strength of neither the Black Sea ports nor the transport fleet substantially lacked for what would later be called "Syrian Express".

If the Russian Federation wanted to preserve its status as a great power and the Syrian crisis gave Moscow a chance to demonstrate this, then the abovementioned negative should be quickly and comprehensively overcame. This required upgraded defense complex, new personnel, a more powerful fleet and ports. And it was necessary to do it quickly and largescaled, in one step solving the whole complex of problems, including overcoming the "revenge of geography". The Black Sea Theater was the most successful from a strategic point of view. With the annexation of Crimea in February-March 2014, the Russian Federation solved the problem of ports through elimination one of the "limitrophs" - Ukraine, making pressure on NATO countries in the most responsible, but vulnerable Southern flank of Alliance, providing the so-called "Syrian express". Thus, Ukraine has been tested, but not entirely: only the southeast with its Russian-speaking population, ports and the unique potential of key enterprises of the defense industry, analogues of which existed or did not exist in the Russian Federation (Nikolaev southern turbine plant and constructor buro "Zarya") or their potential was much higher (for example, "Yuzhmash" from Dnipropetrovsk).

But if the actions in the Crimea hardly could be justified, then the direct acts of aggression in the east and south of Ukraine - could not. That is why, in order to accomplish this task, using the rich and successful historical experience (Vietnam) and theoretical studies of NATO experts (Aras, 2003), as well as the postulates of classical geopolitics, which thanks to a new generation of Russian political scientists (Lebedeva, \& Gajiyev, 1997), the Russian authorities finally mastered, it turned out to be possible to put significant pressure on Ukraine through the creation of a so-called "parallel state" (our term - auth.) and building a complex geopolitical 
configuration in the Black Sea region through the State Formations of the Grayzones System (not controlled or partially controlled by the state) - the Transnistrian Moldavian Republic (despite it does not neighbors the sea it enters the region), the Republic of Abkhazia and the LDPNR. The first is not a recognized state, the second is a partially recognized state, and the third is a "parallel state" and irredentist.

Moreover, the latter indirectly conducts hostilities and political pressure against Ukraine through specially created structures of state formations of the Gray zones system (territories that are not controlled or partially controlled by the state). It is a parallel state of irredentist character Lugansk / Donetsk People's Republics (LDPR) that emerged in 2016, and the Transnistrian Moldavian Republic, which is not a recognized state. Moreover, the partially recognized Republic of Abkhazia also exert indirect pressure on Ukraine in this context.

The term "parallel state" means a certain territory populated by representatives of a predominantly one ethnic group, where an underground or semi-legal (parallel, alternative) governmental structures have been established by specific military-political organization that conducts continuous and prolonged hostilities against the armed forces of a country controlling the territory claimed by specific military-political organization, in order to maximize the mobilization of all available, but very limited economic, demographic, military and political resources to achieve the victory in an internal conflict. Moreover, the legitimacy of these state structures is almost beyond doubt on the part of the residents of the territories within which such military-political organizations operate.

The term "unrecognized state" means an existing, in fact state formation that has separated from a certain country in consequence of radical political changes, but has not been recognized by the world community (hence the origin of the term). The "unrecognized state" is not the subject of international law, as most countries of the world and international organizations officially recognize only the country from which the "unrecognized state" has been separated.

The country from which the "unrecognized state" has emerged uses all its foreign policy and foreign economy potential, as well as the capabilities of its partners, to prevent the entry of the "unrecognized state" into the international arena. As a consequence, the "unrecognized states" remain in such condition during all their existence. At the same time, the government of the losing country is constantly preparing military operations to cease the existence of an "unrecognized state". Given this a two-state clash, it is extremely difficult to liquidate an "unrecognized state". 
Accordingly, if an "unrecognized state" was officially recognized by 2 or more officially existing member states of the world community, it becomes a "partially recognized state".

Nowadays, there is an LDPR association, created in 2016 from LPR and DPR, and since 2000 - a union of not recognized and partially recognized states - the TMR, Abkhazia, South Ossetia and the NagornoKarabakh Republic (Berill et al., 2008). The creation of political-military associations by the Grayzones, all of which gravitate solely to the Russian Federation, led to extremely dangerous geopolitical situation in the Black Sea basin, and Ukraine became its hostage from the geographical and militarypolitical point of view.

To this day, the situation that arose in April 2014 does not even have a theoretical solution as evidenced by the working processes of freezing or reducing the intensity of this conflict within the peacekeeping rhetoric of each of the parties, that directly (Ukraine, Russia) or indirectly (some NATO and the EU countries) are interested in its elimination.

The conflict in the east of Ukraine was and is regional in nature (east and south of Ukraine, that is, a region characterized by specific economic, and ethnic-cultural development). In this regard, it became a logical and ideological continuation of the Crimean conflict (February 22 - March 20, 2014), which in turn also became a classic military-political conflict, where to solve the problem that arose on the Crimean Peninsula in February 2014 either by any means, but without using of military structures, as it was in previous historical periods (December 1991 - mid-April 2014), it was absolutely not possible. However, only for one party (the Russian Federation). Another thing is the character of the armed forces using, which has almost no precedents in history. More or less an analogue of the 2014 Crimean Conflict is the Indo-Portuguese Conflict of 1961 (Indian Operation Vijay), where, with the active use of Indian armed forces, the Portuguese garrisons have shown passivity.

A type of this military-political conflict is exclusively a militarypolitical conflict, because it takes place in the form where the political settlement of it (at the national level - by political methods, at the intergovernmental level - by diplomatic methods) is an officially declared goal. Moreover, it ranks among the states of a single ethno-political space. That is, this military-political conflict clearly correlated with our definition of this concept: interstate or internal state confrontation, characterized by an approximately equal balance between the use and use of military and political instruments, and the ability to resolve it exclusively by political (diplomatic) means. As well as under the definition of G.M.Perepelitsa: 
"This is a social interaction, which is the highest phase (stage) of the development of antagonistic contradictions, which are created by apprehension of political power and the solution of which is achieved by the application or threat of application power to damage one another with the military forces. It consists of two parts: political and military. The first indicates that it is a source of conflict and that can be reached by the conflicting parties. The second part is the armed struggle, where the use of military force is a mechanism of development and conflict resolution" (Prepelitsa, 1996).

That is, our military-political conflict arose as an interaction in the Ukrainian society at the regional (eastern Ukraine) level as a higher phase (stage) of the development of antagonistic contradictions, which were formed on the pretext of political power and the solution of which was reached by the application or threat of infliction. with the help of military force. In this case, the military force conducting the armed struggle can theoretically be stopped (forever or for a while - by the Minsk Arrangement) or adjusted accordingly (transition of the conflict in January 2015 from the average intensity of the fighting phase to a low one).

In January 2015, there was a situation when the active use of the armed forces of the state (Ukraine) did not produce the expected results in time and space. As a consequence, the political or military-political leadership of the respective state has succeeded in limiting their application, turning the military conflict into a military-political one. That is, according to the formulation of GM. Perepelitsa has relied on a political (diplomatic) component that indicates what can be achieved by the conflicting parties. From a purely military point of view, the conflict in eastern Ukraine is military, of low intensity. It emerged as an internal political de jure, and de facto developed into an interstate military political. That is, we have a "new type conflict". Our conflict, despite its local (only two areas) nature, is in essence a regional conflict - East of Ukraine. For Ukraine, it is conducted in a scale of not full region of the country with access to the sea, that makes it by all characteristics as strategic, interstate. Our conflict is difficult and subordinate, since the opposite side for Ukraine is the de jure confederation of non-recognized states (DPR - LPR), and the de facto parallel state of irredentist nature - the LDPR, which is indirectly supported by a great state the Russian Federation. From this perspective, for Ukraine, this conflict is one in which our country simply cannot win.

In fact, this is a conflict between an officially recognized state and an amorphous coalition of three straight brands - LPR + DPR - LDPR - RF.

The essence of Ukraine's actions in this conflict is: 
- Search for political allies, situational by purpose for:

- 1. Diplomatic support of Ukraine and the corresponding pressure on the Russian Federation;

- 2. For the purpose of supplying (acquisition by Ukraine) of weapons.

The fighting ations of our conflict:

- In the first stage (April 2014 - January 2015) - average intensity;

- In the second stage (from January 2015) - low intensity.

By geography - local conflict. In terms of forces and means involved, only land forces with limited use of aviation and navy forces. For generations of military equipment involved - the third post-war generation with elements of precision and network-centric weapons. By strategy: direct actions for Ukraine; - for opponents of Ukraine - not direct and cognitive actions. The conflict is: - between the states of one socioeconomic system; - between countries of different levels of development. For purposes and reasons, this is an irredentist conflict (not a separatist one, as it accepted to name it). By nature, it is an exclusively political conflict with the active use of militant formations and with an understanding of its settlement only by political (diplomatic at the interstate - Ukraine - RF level) methods. Thus, this conflict is an original, however classic, military-political one.

However, as of the fall of 2019, all parties to the conflict in eastern Ukraine declared their desire for a peaceful settlement. If this is completely understandable for the direct participants of Ukraine and the LDPR, then the question arises as to why its indirect participant - a great power "the Russian Federation" - accepts it? It goes without saying that without its support, the LDPR will soon find itself in a situation close to real and rapid death. Since, through our definition of a "parallel state" (and the LDNR as it is), its existence proceeds only in the conditions of permanent military conflict and its "survive" depends on the direct support from at least one strong, and better, a great state. In our view, the Russian Federation is aimed at ending or freezing the conflict in the East of Ukraine because of the real achievement of its main fundamental goal. Surprisingly, but clearly the "apple of contention" for Ukrainian-Russian relations was formulated in 2009 by the late leader of the Great Libyan Jamahiriya Muammar Gaddafi: "According to the official point of view, Russians today do not dispute the independence of Ukraine and even admit that Ukraine is a sovereign independent state, neighbor and sister. Then what is a real serious problem? A serious problem is that Ukraine wants international guarantees for its independence, for not to lose it. Therefore, what Russia sees as a threat to 
its security and independence, for Ukraine it is a guarantee of its security and independence. This is a serious disagreement in the policies of the two states.

It is clear why Ukraine wants to join the EU and NATO, considering that this is a "guaranteed guarantee" of its independence. Russia, however, believes that such guarantees are directed against her, not against any other country. Russians say that guarantees that Ukraine wants are very serious security challenges for Russia. They argue that such guarantees are unnecessary, since Russia has already recognized Ukraine as a sovereign independent state. Russia can be understood. If NATO comes to Ukraine, it means a knock on its door for Moscow. And if the enemy knocks on your door, then either open it to come in, or it would break the door. But Russia replies that the danger is not only in the presence or absence of military bases, but that in this case the Ukrainian territory will become NATO territory, and the alliance will be present here even without stationary bases for deployment of NATO troops, since the Ukrainian armed forces will be in the framework of the armed forces of the Allies. And this is considered inadmissible for Russia, as regards to its security.

At the same time, Ukrainians argue that they only require international guarantees of independence of their country and do not want to create a threat to Russia. And for confirmation of this, they are ready to sign any document with the Russians, which will fix the obligation that Ukraine will not be a source of threats to the Russians. Some Russians believe that the threat will necessarily arise as soon as Ukraine becomes a member of NATO, an alliance that sees the majority of the population of Russia as an enemy" (Kaddafi, 2009).

The creation of a fire in the East of Ukraine and even its termination in a situation where the relations between Ukraine and Russia in the perspective will not reach a pre-conflict level is completely beneficial to the Russian Federation, since this is already a guarantee for Ukraine's notaccession to NATO based on the charter documents of the Alliance. Therefore, the main geopolitical task in the conflict in the Eastern Ukraine is fulfilled by Moscow.

It is believed that such a situation on the part of Ukraine's opponents is conditioned by the achievement by the Russian Federation of its main goal in this conflict - an actual elimination of real opportunities for Ukraine's accession to NATO. The creation of a fireplace in the east of Ukraine and even its termination in a situation when the relations between Ukraine and Russia in the perspective will not reach a pre-conflict level is completely beneficial to the Russian Federation, since this is already a 
guarantee for Ukraine's non-accession to NATO based on the charter documents of the bloc. Therefore, official Moscow fulfilled the main geopolitical task in the conflict in eastern Ukraine.

However, there is another reason for such steps by the Russian leadership, namely, the certainty of an official Moscow in winning the conflict in eastern Ukraine on the cognitive front, that clearly viewed and views through the social networks. Namely they became instruments of geopolitical influence, which Russia fully used during annexation of Crimea and launching of war in the east of Ukraine. The pro-Russian pages "In Contact" created the image of Ukraine as a foreign country for the population of Donbas and Crimea, Southeastern Ukraine - as part of Greater Russia, NATO and the EU - as the main enemies whose actions have led to the conflict.

The narrative concerning Ukraine was dominated by the theme of describing the actions of the Ukrainian military and the Ukrainian authorities as "punishers", making an emotional message and appealing to allegories of World War II, which was intended to deepen Ukraine's sense of the enemy. The second dominant issue was the questioning of Ukraine as a political entity, through its appeal to it as a "political project that failed ". A third theme for Ukraine was the widespread criticism of the former Ukrainian authorities, which was referred to as the "Kyiv authorities" to emphasize that capital's interests differ from local interests. The previous three major turns of the geopolitical narrative were complemented by themes of domination of oligarchs in Ukraine, who exploited the population and who make arbitrariness by violation of human rights and freedoms, as well as memory policies.

Russia, in its turn, created the opposite image of a "great power" capable of withstanding an enemy and culturally closer to the Southeastern Ukraine (the essence of term "Novorossiya" using), and the annexation of Crimea was used as the main confirmation and main "success story" in proRussian narratives. For Moscow, it was extremely important to oppose Russia's participation in conflict and to define the USA and NATO as the main enemies that gave rise to the armed conflict and the Ukrainians as "punishers" who embody the will of the US as a geopolitical center.

All these are complex elements of the system of cognitive war that Ukrainian scientists I.P. Rushchenko and N. V. Zubar qualitatively exposed in a number of their publications (Rushchenko \& Yubar, 2017). Taking into account their conclusions, we note that social networks have struck on three key structures that form public opinion in the state and national conceptual foundations - on science, education and expert society. The schism and 
creation of scientific concepts, which are considered by the scientific community from extremely opposite points of view (especially in the history and sociology), should be considered in any scenarios as beneficial to the official Moscow.

\section{Conclusions}

Because of this, any form of conflict settlement in the East of Ukraine is potentially beneficial to the Russian Federation. And given that the Russian leadership by its "peacekeeping" actions regarding the conflict in the east of Ukraine made a split in NATO and the EU monoliths, it should be assumed that termination or freezing conflict will strengthen Russia's positions. However, the main thing is that the Russian leadership through its actions in the context of the conflict in the eastern Ukraine worked out a scheme of further foreign policy expansion in any direction under the scheme of "creeping aggression" or "silent occupation". Therefore, without the creation of a comprehensive coalition scheme to counteract these measures by all interested parties, the explosiveness of the situation in the Eastern Europe will increase.

\section{References}

Aras, D. (2007). Chetvertaya mirovaya voyna [Fourth world war]. Astrel.

Berill, S. I., Galynskiy, I. N., \& Blagodatskykh, I. M. (2008). Ot samoopredelyeniya k mezhdunarodnomu priznaniyu: Abkhaaiya, Nagorniy Karabah, Pridnestrovie, Yuгhnaya Osetiya [From self-determination to international recognition: Abkhazia, Nagorno-Karabakh, Transnistria, South Ossetia]. Tyraspol.

Gay-Nyzhnik, P. P. (2017). Rossiya proti Ukraini (1990-2016 rr.): Vid politiki shantazhu do viyni na poglinannya ta sproby znishchennya [Russia against Ukraine (1990$2016 \mathrm{rr}$.): A type of policy of blackmailing to chastening and to slaughtering]. MP Lesya.

Kaddafi, M. (2009). Ukraina - nebezpechna problema [Ukraine is not a safe problem]. Moscow.

Kaplan, P. (2015). Mest geographii. Chto mogut rasskazat geographyheskiye karty o gryadushchib konfliktah I bitve protiv neizbezhnogo [Places of geography. What geographic maps can tell about upcoming conflicts and the battle against the inevitable]. KoLibry.

Lebedeva, M., \& Gajiyev, K. S. (1997). Mez̧bdunarodnye processy [International processes]. International Relations. 
Perepelitsa, G. N. (1996). Voenno-politicheskiy conflict: metodologiya issledovaniya i uregulirovaniya [Military-political conflict: research and settlement methodology] [Unpublished doctoral dissertation]. Kyiv.

Rushchenko, I. P. (2015). Rossiysko-Ukrainska gybridna viyna: Poglyad soiologa [RussianUkrainian hybrid war: A glance from a soiologist]. FOP Pavlenko O.G.

Rushchenko, I. P., \& Zubar, N. V. (2017). Viyna informatsyi [Information war]. Oboronniy Vysnik, 8, 4-12.

Troyan, S., \& Kiridon, A. G. (2014). 2008 - Ukraina 2014: zaparallelennya rosiysykih stratagem [2008 - Ukraine 2014: Parallelism of Russian stratagems]. Zovnishny Spravy, 8, 33-37. 